ISSN:

Print - $2277-078 \mathrm{X}$

Online - $2315-747 \mathrm{X}$

(c) UNAAB 2017
Joumal of
H umanities, Social
Sciences and Creative Arts

\title{
EVALUATION OF VIABLE OPERATING STRATEGIES FOR PUBLIC TRANSPORT BETWEEN FUNAAB CAMPUS AND CAMP TERMINUS IN ABEOKUTA
}

\author{
1S. O. ODUNFA., 2A.A. ADEKUNLE AND 3S.I. OLATUNJI \\ D epartment of Civil Engineering, Federal University of Agriculture, Abeokuta \\ ${ }^{1 *}$ Comespondence Author:Simeon_olutayo@yahoo.com Tel +2348035363995
}

\begin{abstract}
Transportation is a live wire for national development regardless of a nation industrial capacity, population or technological development. It gives expressions to policy initiative in areas like health, education, employment, etc., and in the absence of it, these facilities would be inaccessible. Viable operating strategies for public transport between Federal University of Agriculture, Abeokuta (FUNAAB), Ogun State Nigeria Campus and Camp Terminus in Abeokuta were evolved. Traffic study was conducted for seven (7) days to determine traffic volume and peak periods (morning and evening) along the route. Questionnaires were administered to the road users to obtain factors (availability of vehicles, travel time from Camp Terminus to FUNAAB, road condition, operational cost, comfortability of the vehicle) needed to generate operating strategies. These factors were subjected to statistical analysis. The traffic volume revealed that Private cab had the highest traffic flow for a.m. peak period (8: 00 - 9: 00 am) from Mondays to Thursdays while Public cab had the highest on Fridays to Sundays, and at the pm peak period (4:00 - 5:00 pm), Public cabs had the highest traffic volume on Wednesdays, Saturdays and Sundays while the Private cabs had the highest on the rest days of the week. The analysis of the sampled population showed that public cab had the least total time travel (36.1 minutes) followed by mini- bus ( 37.8 minutes) while the school bus had the highest (43.7 minutes) and this justified the reason why $40 \%$ of the population choose to travel by public cab, $33 \%$ by mini- bus and $27 \%$ by the school bus. However, for the viability of the operating strategies, more public cab and minbuses should be provided to ply the road because of their lesser travel time, also provision of more school buses because of the large number of passengers they carry per trip should be provided.
\end{abstract}

Keywords: Evaluation, Operating strategy, Transportation, Traffic volume, questionnaires

\section{INTRODUCTION}

Transportation is the main engine that spatial interaction, locational changes and intedrives the growth and development of grates various regional spaces. (Somuyiwa $\&$ al., societies, people and countries at large. (2011) and Oyesiku (2002), at different times The provision of transport facilities and also perceived transport as one of the elemental services is indispensable as a means of factors for any land use development pattern; it conveying people, goods and information forms intrinsic part of settlement development through places for the socio-economic neededto open up regions provides access to and cultural integration of nations natural resources. According to Mustapha, 
2017, a reliable and efficient transportation system is one of the key factors that play an important role in a region's economic growth by providing an adequate access which is a necessary condition for the efficient operation of manufacturing, retail, labour and housing markets.

It accelerates nural, urban and national development by making goods and services available to industry and consumers; creating opportunities for social and economic interaction and employment. Indeed, transport could be said to be the key means of giving expressions to policy initiative in areas such as health, education, etc. It gives life to development, stimilates improves hunan existence on earth and reduces distance for man's trips in space G unnarson, 1998; Spaething, 1999; Oni, 2001; Atubi, 2006).

However, transportation problems remain one of the most worrisome in Nigeria today both in urban and rural areas. Among the most notable problems in Nigerian cities are long waiting times for buses, traffic congestion (especially both in the morning and evening peak periods), parking difficulties, air pollution,road traffic accidents (Asiyanbola 2007; Aderamo, 2010; Aderamo, 2012; Ashiedu, 2011) and inability to predict travel time. This results in daily loss of time and energy in various urban centres (Solanke, 2013). These problems could be minimized if there is adequate and proper transport system management. An efficient transport system would lower the cost and reduces the time of moving goods and service to where they can be used more efficiently (Edith, 2013). According to Atubi, 2010, Transport System Management (TSM) is described as making existing transport systems efficient as possible and provision for short-range transportation needs.
Federal University of Agriculture, Abeokuta (FUNAAB) and its environs as a community is not free of these problems as population increases on daily basis leading to influx of commuters demanding for the few vehiclesavailable during the peak periods. In order to minimize these problems, it is important that efficient traffic management measures in addition to other remedial measures like developing attractive public transport service as an alternative operating strategies are put in place (Banjo, 2008, Federal Government of Nigeria, 2010) to improve the traffic condition. This can be done when thorough understandings of the structure of the community and transport needs are properly evaluated.

Evaluation of alternative operating strategies is important to set out targets for the effective and excellence transport services to address the needs of potential road users. It requires an effective transport network to gives the public access the opportunities and benefits that contribute to better quality of life. Also, a thorough understanding of existing travel pattern is necessary for identifying and analyzing existing traffic related problems.

For an effective operating system, a good road network is necessary to enhance smooth ride thereby making planning ofa journey or predicting arrival time possible and reduce accident occurrence.

This paper therefore looks into the operating strategies for public transport services between FUNAAB and the Camp Terminus with a view to determining alternative strategies for effective services within the system. 


\section{MATERIALS AND METHODS Sturdy Area}

The road evaluated in this study is anerstwhile which has been constructed over years. The road lies on the North - North South of Abeokuta, capital city of Ogun state in Nigeria. The road which is $4.5 \mathrm{~km}$ length away from FUNAAB ceremonial gate connects Federal University of Agriculture, Abeokuta (FUNAAB) O gun State campus and Abeokuta - Ibadan express road at a T intersection junction (Figure 1).

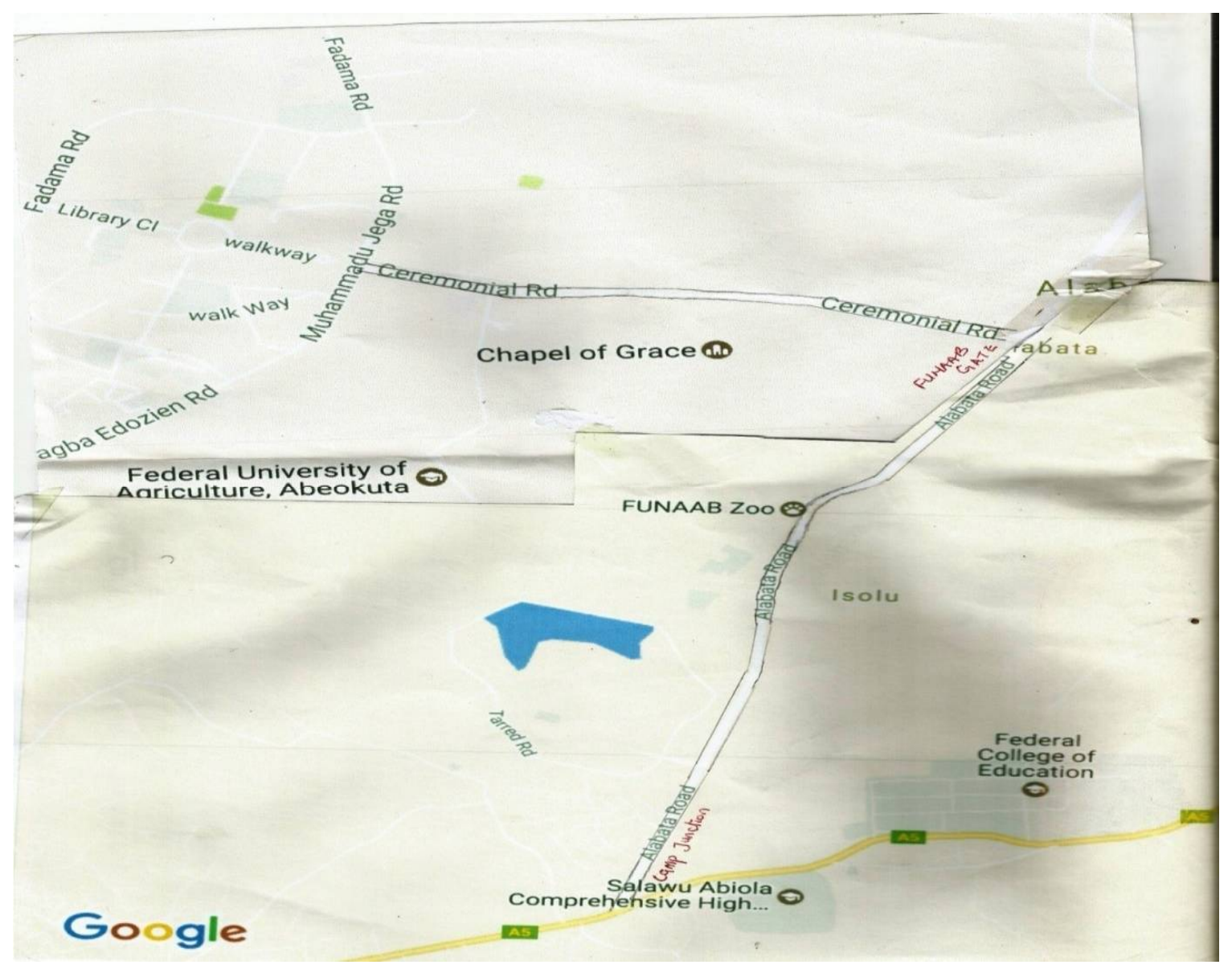

Figure 1: Route Location Map

\section{Methods}

Traffic study was conducted manually along the road for a period of 7 days that involved 12 hours daily counting (7:00 am to 7:00 pm) to determine the traffic volume (Average Daily Traffic). The traffic study was conducted at three major points along the study road: (i) Camp Junction

(ii) O gun - O shun River Basin D evelopment Authority Junction and

(iii) FUNAAB Ceremonial Gate

Peak hour was noted both in the morning and in the evening during the exercise be- 
tween 8:00 - 9:00 a.m. and 4:00 - 5:00 pm The summary of the traffic count results are respectively. A nalysis of the total number of vehicles plying the road was done.

Oral interview was conducted for the populace and drivers who cannot read while questionnaire was used for other members of community who can read and write separately to obtain data such as transport fares, travel time, personal security and comfortability. Thereafter analysis was carried out and evaluation of the alternative operating strategies of the road was done to have a thorough knowledge and understanding of the pattern of traffic, congestion time of vehicles without passengers; passengers without vehicles, justification of the cost of operation of the service providers and frequency of operation.

shown in Figures 2 and 3.The traffic counts revealed that Private cab had the highest traffic flow for a.m. peak period (between 8: 00 and 9: $00 \mathrm{am}$ ) from Mondays to Thursdays. This implied that other road users (public cab and school bus) were not many and possibly other community members who have no access to private vehicles would arrive late to their destinations within this period. But on Fridays to Sundays, Public cab had the highest traffic flow (Figure 2), and probably this could be due the fact that most road users with personal vehicles have gone for weekend holidays and very few public cabs have taken up the advantage to serve the community members who are without private vehicle.

\section{RESULTS AND DISCUSSION}

\section{Trafficstudies}

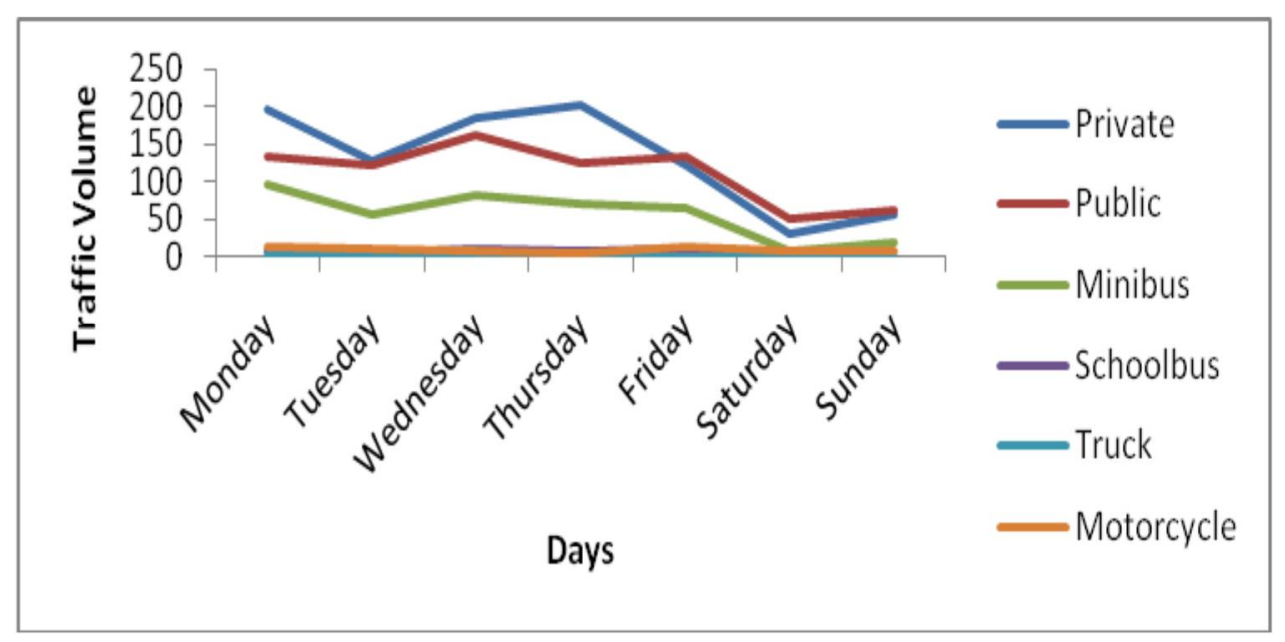

Figure 2: D aily traffic volume trend during the morning peak period 
Also, it was observed that after the a.m. noon session of their operation. This period peak hour $(8-9 \mathrm{am})$, there were vehicles of operation ends at between 5 p.m. and 6 lying down without passenger and the rate p.m. depending on the number of waiting at which public cabs operate got reduced. passengers. At the pm peak period, Public The operation of FUNAABOT bus services cabs had the highest traffic count only on was observed to be between 8 and 10 am Wednesdays, Saturdays and Sundays while after which they park until the p.m. peak the Private cabs had the highest on other hour (4 - 6 p.m.) when they start the after- days (Figure 3).

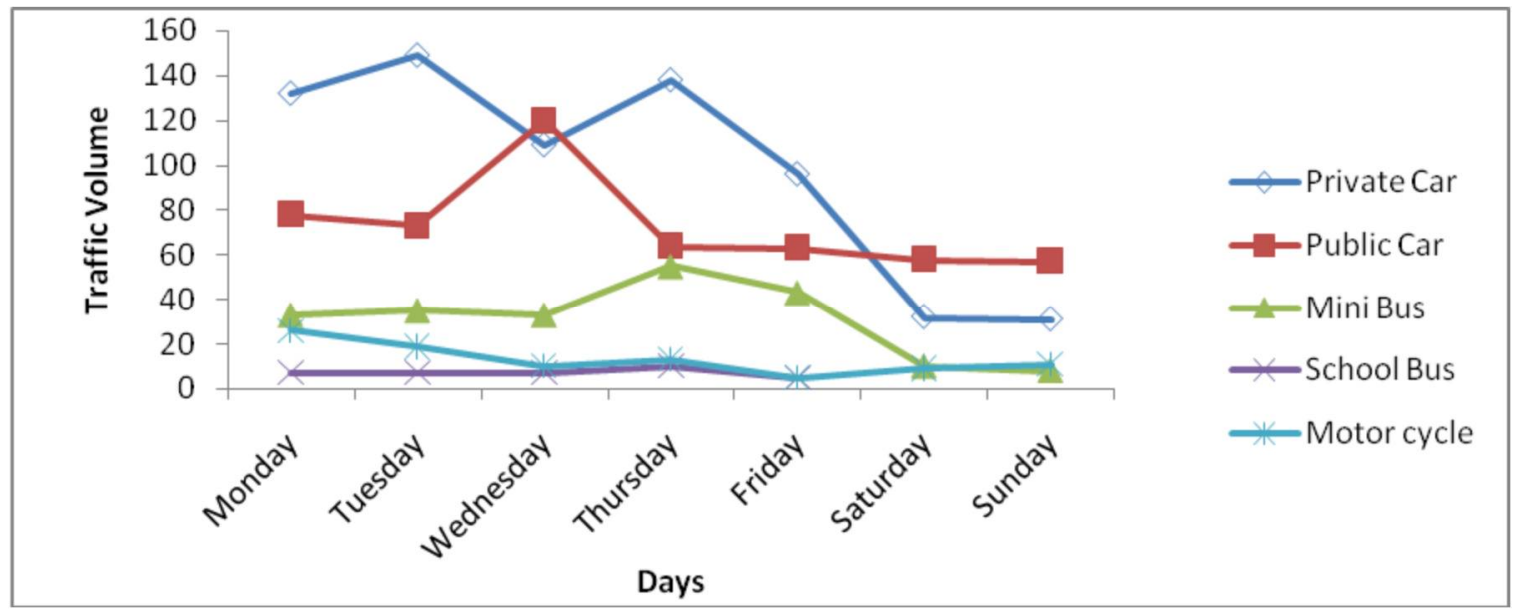

Figure 3: Daily traffic volume trend during the evening peak period

Generation of AltemativeOperatingStratejies

The waiting time (before the arrival of vehicles at Camp junction) and Travel time from Camp junction to FUNAAB were estimated as shown in Tables 1-2. Public cabs had the highest percentage both for waiting time (49.70\%) (Table 1) and travel time (49\%)(Table 2) while mini bus and school bus were $25.45 \%$ and $24.85 \%$ respectively for the waiting time (Table 1). But for the travel time, mini bus had the least value (22.48\%) (Table 2).

Table 1: Estimated waiting Time before the arrival of vehicles at Camp junction

\begin{tabular}{llllll}
\hline $\begin{array}{l}\text { Total Time } \\
\text { (minutes) }\end{array}$ & Public cab & Mini bus & School bus & Total & $\begin{array}{l}\text { Percentage } \\
(\%)\end{array}$ \\
\hline $0-5$ & - & - & - & - & - \\
$5-10$ & 10 & 5 & - & 15 & 9 \\
$10-15$ & 25 & 18 & 10 & 53 & 32 \\
$15-20$ & 20 & 12 & 18 & 50 & 30 \\
$20-25$ & 12 & 7 & 8 & 27 & 17 \\
$25-30$ & 15 & - & 5 & 20 & 12 \\
Total & 82 & 42 & 41 & 165 & 100 \\
Percentage (\%) & 49.70 & 25.45 & 24.85 & 100 & \\
\hline
\end{tabular}

J. Hum. Soc. Sci. Crtv. Arts 2017, 12: 120-128 
S. O. ODUNFA., A.A. ADEKUNLE and S.I. OLATUNJI

Table 2: Estimated Travel Time while on board from Camp junction to FUNAAB

\begin{tabular}{llllll}
\hline $\begin{array}{l}\text { Total Time } \\
\text { (minutes) }\end{array}$ & Public cab & $\begin{array}{l}\text { Mini } \\
\text { bus }\end{array}$ & School bus & Total & Percentage (\%) \\
\hline $0-5$ & & & & & \\
$5-10$ & & & & & \\
$10-15$ & 60 & 10 & & 70 & 42 \\
$15-20$ & 21 & 15 & 22 & 58 & 35 \\
$20-25$ & - & 12 & 25 & 37 & 23 \\
$25-30$ & 81 & 37 & 47 & 165 & 100 \\
Total & 49.09 & 22.42 & 28.48 & 100 & \\
\hline Percentage (\%) & & & & & \\
\hline
\end{tabular}

Table 3 presented the Total Travel Time vealed that public cab had the least travel per trip (Camp junction - FUNAAB - time from Camp junction to FUNAAB (18.8 Camp junction). The statistical analysis re minutes) followed by the mini - bus (22.8

Table 3: Analysis of Total Travel Time per Trip (Camp junction - FUNAAB - Camp junction)

\begin{tabular}{|c|c|c|c|c|c|c|c|c|c|}
\hline & \multicolumn{3}{|c|}{ Public cab (Minutes) } & \multicolumn{3}{|c|}{ Mini bus (Minutes) } & \multicolumn{3}{|c|}{ School bus (Minutes) } \\
\hline & Mean & $\begin{array}{l}\text { Standard } \\
\text { deviation }\end{array}$ & $\begin{array}{l}\text { Vari- } \\
\text { ance }\end{array}$ & Mean & $\begin{array}{l}\text { Stan } \\
\text { dard } \\
\text { devi- } \\
\text { ation }\end{array}$ & $\begin{array}{l}\text { Var } \\
\text { ianc } \\
\mathrm{e}\end{array}$ & $\begin{array}{l}\mathrm{Me} \\
\text { an }\end{array}$ & $\begin{array}{l}\text { Stand- } \\
\text { ard } \\
\text { devia- } \\
\text { tion }\end{array}$ & Variance \\
\hline $\begin{array}{l}\text { Travel Time } \\
\text { while on board } \\
\text { (Camp to } \\
\text { FUNAAB) }\end{array}$ & 18.8 & 2.19 & 4.80 & 22.8 & 3.85 & $\begin{array}{l}14 . \\
82\end{array}$ & $\begin{array}{l}25 . \\
2\end{array}$ & 2.50 & 6.23 \\
\hline $\begin{array}{l}\text { Waiting Time } \\
\text { before vehicles } \\
\text { arrived back at } \\
\text { Camp }\end{array}$ & 17.3 & 6.46 & 41.73 & 15 & 4.53 & $\begin{array}{l}20 . \\
52\end{array}$ & $\begin{array}{l}18 . \\
5\end{array}$ & 4.71 & 22.22 \\
\hline $\begin{array}{l}\text { Total Travel } \\
\text { Time }\end{array}$ & 36.1 & & & 37.8 & & & $\begin{array}{l}43 . \\
7\end{array}$ & & \\
\hline
\end{tabular}


But considering the waiting time for the because of its least travel time, its arrival and vehicle to arrive back at Camp, mini - bus comfortability.

had the least (15 minutes) followed by the This leaves the average community member public cab (17.3 minutes) while the school who has to be in FUNAAB between the bus had the highest value (18.5minutes). hours of 8 and 9 am to be at the bus stop The estimated total travel time revealed that between $7-8 \mathrm{am}$.

public cab had the least total time of 36.1 Choosing between the mini bus and the minutes and this is justified by the question- school bus is left to when the public cab is naire results, where $40 \%$ of the sampled not available or when cost is of higher conpopulation reported their choice of public sideration than time saving. cab for mode of transportation (Table 4)

Table 4: Reasons for choice of mode of Transportation

\begin{tabular}{llllll}
\hline & & & & & \\
Reasons for Choice & Public & Mini bus & School bus & Total & Percentage (\%) \\
\hline of mode of Transportation & cab & & & & \\
Short waiting time & 23 & 12 & - & 35 & 21 \\
Short travel time & 33 & 20 & - & 53 & 32 \\
Low fares & - & 23 & 44 & 67 & 41 \\
Comfortability & 10 & - & - & 10 & 6 \\
Total & 66 & 55 & 44 & 165 & 100 \\
Percentage (\%) & 40 & 33 & 27 & 100 & \\
\hline
\end{tabular}

However, for an improvement in the trans- mary of the response from the community portation services, Table 5 gave the sum- members.

Table 5: Questionnaire to improve Transportation services along Camp junction to FUNAAB

\begin{tabular}{lll}
\hline Suggestions & Respondents & Percentage (\%) \\
\hline $\begin{array}{l}\text { Provision of more intra - campus transporta- } \\
\text { tion services (public cab, mini buses and bus- }\end{array}$ & 77 & 46.67 \\
es) & 82 & 49.70 \\
Repairs of road & 6 & 3.63 \\
Provision of FUNAAB car park at Camp & 165 & 100 \\
\hline Total & & \\
\hline
\end{tabular}


Based on the analysis of results obtained, the following provisions were made for viable operating strategies between FUNAAB campus and Camp Terminus in Abeokuta.

(i) Provision of more intra - campus transportation services (public cab and min-bus) to ply the road because their total time travel per trip is less.

(ii)Provision of more school buses because of the large number of passengers they carry per trip.

(iii) Repair of road from FUNAAB campus to Camp Terminus will also attract more commercial vehicles to ply the road and thereby reduce the waiting time for the arrival of vehicles at the bus stop.

\section{CONCLUSION}

Problems of the transportation system along this road are due to insufficient number of vehicles and distribution over time at the most demanding periods (a.m. and p.m. peak periods). It was discovered that various factors such as the road condition, low turnout by the road users during the off peak periods, few or no passenger from the university community during a.m. peak periods and to the university community during p.m. peak periods were responsible for low patronage of the commercial vehicles. Also, the total travel time influenced the choice of vehicle by the commuters as they preferred the vehicles with the least average total time. However, for the effectiveness of the transportation system on this road, it is suggested that more public cab and min-bus should ply the road because their travel time is less, provision of more school buses because of the large number of passengers they carry per trip andputting the road in proper condition should be done.
REFERENCES

Aderamo A. I. (2010). Transport in Nigeria: The case of K wara State. African Ecomamic andBusiness Rexiew8(1): 19 - 40.

Aderamo A. J. (2012). Urban transportation problems and challenges in Nigeria: A planner's view, 2(3):198-203.

Ashiedu C. M. 2011. An assessment of bus rapid transit system as a strategy for urban traffic management in Lagos metropolis. Unpublished B.Sc. Project.

Asiyanbola R. A. 2007. Intra-urban transportation, gender and psychological distress in developing countries: Nigeria. Paper presented at PRIPODE Workshop on Urban Population, D evelopment and Environment Dynamics in D eveloping Countries, June 11 -13, Nairobi, Kenya.

Atubi A.0. 2006. Road Traffic Acidant Pattems in Lagos State from 1970 to 2001 . Unpublished Ph.D. Thesis, University of Nigeria, Nsukka, D epartment of G eography.

Atubi A.0. 2010. An Intemational MultiDisaplinaryJaumal, Ethiqua 4 (4):459-470

Banjo G. A. 2008. Integrated mass transit in Nigeria's Cities: Issues challenge and options. Paper presented at the Lamata National Conference on Public Transportation, Lagos, Ikeja.

Edith A. 0., Adebayo A. E. 2013. The Role of Road Transportation in Local Economic Development: A Focus on Nigeria Transportation System.

Federal Govemment of Nigeria. (2010). D raft National Transport Policy. 
Gunnarson S.0. 1998. "Traffic Managemet narC. Planningfor SustainabilityPTRC. for Histaric Cities in Europe". Prepared for the OECD Seminar in Barlelona 29-30 March. 4 (4), Serial Na 17, Oddber, 2010. Pp 459470.

Oyesiku 0.0. 2002. From Worb to Tarb 24th Inaugural Lecture, Olabisi Onabanjo University.

Kingsley E., Christopher A. 2014. Mass Transportation System in Nigeria: Strategies for Effective Maintenance Culture in Public Sector O perations of Enugu State.Jarmal of Enegy Techndoges and Pdigyuwwiistearg4(1).

Mustapha M. 2017. Overview of Urban Transportation Problems in Nigeria, Professor. Mustapha Muktar Archives, Friday, September 15, 2017.

Oni B. 2001. Future Urban Transport and Urban Land use Revitalization of Public Transport. Transpat FoumProcedings of Semi-

Solanke M.0. 2013. Challenges of urban transportation in Nigeria Intemational Jaumal of Dedqpmentand Sustainability, 2(2):891-901.

Somuyiwa A.0., Oyesiku 0.0., Dosunmu V.A. 2011. Transport and logistics research and its impact on capacity building of local institutions in Nigeria, Am J. Sa. Ind $\operatorname{Res}, 2(4): 559-566$.

Speathing D. 1999. "Sustainable Transportation: The American Experiences" in 24th European Transport Forum. Procedings of Seminar C. Planingfor SustainabilityPTRC.

(Manusaipt reeived 8thDeember 2015 accepted 23rd July, 2018). 